ORIGINAL PAPER

Eur. J. Histochem.
45: 249-258, 2001
(C) Luigi Ponzio e figlio - Editori in Pavia

\title{
Ultrastructural and immunocytochemical characterization of interstitial cells in pre- and postnatal developing sheep pineal gland
}

\author{
E. Redondo ${ }^{1}$, A. Franco ${ }^{2}$, A.J. Masot ${ }^{1}$, and S. Regodón ${ }^{2}$ \\ ${ }^{1}$ Department of Histology and ${ }^{2}$ Anatomy, Faculty of Veterinary Medicine, University of Extremadura, 10071 \\ Cáceres, Spain
}

Accepted: 20/3/01

Key words: phosphotungstic acid hematoxylin, glial fibrillary acidic protein, vimentin, second cell populations

\section{SUMMARY}

Pineal gland interstitial cells from 32 sheep embryos (from day 54 of gestation until birth ) and 18 sheep (from 1 month to $>2$ years) were analysed using ultrastructural and immunohistochemical techniques. From day 98 of gestation and throughout postnatal development, a second cell type was observed in addition to pinealocytes; these cells displayed uniform ultrastructural features similar to those of CNS astrocytes. Ultrastructural homogeneity was not matched by the results of histochemical and immunohistochemical analysis. Expression of phosphotungstic acid hematoxylin, glial fibrillary acidic protein and vimentin indicates that the second cell population in the developing ovine pineal gland is, in fact, a combination of glial-astrocyte cells at varying stages of maturity. Pineal interstitial cells started to show signs of functional activity evident in vascular tropism; such activity, evident from around day 98 of gestation, appeared to relate to the exchange of substances between the pineal parenchyma and blood vessels and, though it continued throughout postnatal development, was most evident in animals slaughtered between 9 months and 2 years of age (group II). Morphologically, functional activi- ty in interstitial cells in this age-group was apparent in: 1, formation of specific contact sites between interstitial cells and nerve fibres in the perivascular space; and 2, the presence of numerous gap junctions between the bulbous endings of cytoplasmic processes.

\section{INTRODUCTION}

The pineal originates as an outgrowth of the roof of the diencephalon in all vertebrate species. This evagination arises between the developing habenular commissure anteriorly (or rostrally) and the posterior commissure and subcommisural organ posteriorly (or caudally) [Shedpure and Kumar, 1995 ]. The pineal gland, in all vertebrate species, is composed of pinealocytes and a second cell type variously termed interstitial cells (Huang et al. 1984; Cozzi 1986; Karasek and Reiter 1992; Redondo et al. 1996; Regodón et al., 1998a,b ), Type II pinealocytes (Calvo and Boya, 1983; 1984 a,b; Boya and Calvo, 1984), glial cells (Calvo et al. 1988a; López-Muñoz et al. 1992a; Borregón et al. 1993), or astrocytes (Xu Zang et al., 1985; LópezMuñoz et al., 1992b; Boya and Calvo, 1993). 
The nature of these cells has been studied using silver impregnation methods with gold chloride sublimate (Del Rio-Hortega, 1922). Electron microscopic studies of the pineal gland in mice and rats (Luo et al., 1984; Schachner et al., 1984; Calvo and Boya, 1984b, 1985; Calvo et al., 1988b), golden hamsters (Huang et al., 1984), carnivores (Calvo et al., 1988a, 1990; Boya et al., 1995), horses (Cozzi, 1986) and ruminants (Redondo et al 1996) have all pointed to the abundance of intermediate filaments in the perikaryon and cell processes as the most striking ultrastructural feature of these cells.

In 1978, Moller et al. demonstrated the presence of glial fibrillary acidic protein (GFAP) positive cells within the rat pineal gland parenchyma. These cells were identified as interstitial cells and a glial nature was postulated in rodents. Subsequent studies have confirmed the presence of GFAP in interstitial pineal cells in various mammals (Huang et al. 1984; Schachner et al. 1984; Suárez et al. 1987; Calvo et al. 1988a; Li and Welsh 1991; Franco et al. 1997). Previous research has shown that interstitial cells express the intermediate filament protein vimentin (VIM) (Calvo et al. 1988a; López-Muñoz et al. 1992a); vimentin has even been considered a valid label for immature astrocytes (Borregón et al. 1993).

Most studies addressing the nature of this second cell population have been performed in adult animals. Other than one paper by Franco et al. (1997) no published studies have dealt with the pre- and postnatal development of ovine pineal interstitial cells. There are two major reasons why such research is necessary: 1.- to fill out our very limited knowledge of these cells; and 2.- to use immunoelectron microscopy for the precise identification of these cells.

The present paper reports on the immunohistochemical and ultrastructural characteristics of sheep pineal gland interstitial cells during pre- and postnatal development.

\section{MATERIALS AND METHODS}

\section{Animals: Prenatal development}

Thirty-two sheep embryos at varying stages of development, ranging in age from 54 to 150 days, were used for this study. Specimens were divided into four age-groups, each containing eight embryos (four male and four female): group 1 (54 to 67 days of gestation), group 2 (71 to 92 days), group 3 (98 to 113 days) and group 4 (118 to 150 days). Embryos were obtained using methods reported elsewhere (Redondo et al. 1996; Franco et al. 1997; Regodón et al. 1998a,b).

\section{Animals: Postnatal development}

Eighteen Merino sheep ranging from 1 month to $>2$ years in age were used for this study. Sheep were divided into three age-groups, each containing six animals (three male, three female): group I ( 1,3 and 6 months), group II (9 months, 1 year and 2 years) and group III (>2 years). Grouping followed current physiological and zootechnical criteria.

Animals were exposed to a natural light cycle and given ad libitum access to food and water. After sedation with an intramuscular injection of propionyl phenothiazine $(0.5 \mathrm{mg} / 100 \mathrm{Kg}$ body weight), animals were slaughtered by jugular vein administration of $2 \mathrm{~g}$ sodium thiopental as a $20 \%$ aqueous solution at 10:00 A.M. between February and June.

\section{Light microscopy}

Embryo and adult sheep pineal glands were sliced parasagitally after 1 hour in Carnoy's fluid. One of the two portions thus obtained was fixed in $10 \%$ neutral formalin saline and processed by paraffin-embedding methods. Sections $6 \mu$ m thick were cut and stained with phosphotungstic acid hematoxylin (PTAH) for detection of glial-type cells (Franco et al., 1997).

\section{Light immunohistochemical analysis}

ExtrAvidin peroxidase staining (EAS) was carried out on deparaffinized pineal samples for detection of GFAP and VIM (considered as glial cell markers). Sections were incubated in diluted (1:50) normal swine serum for 15 minutes to reduce background. The following primary antisera (Sigma-Aldrich Química S.A., Madrid, Spain; no. G-3893 and No. V-5255) were used for 3 hours at $20^{\circ} \mathrm{C}$ : 1) 1: 400 monoclonal anti-human GFAP, 2) 1:20 monoclonal anti-human VIM. Diluted (1:200) biotinylated goat anti mouse IgG (Sigma-Aldrich Química S.A., Madrid, Spain; No. B-7151) was placed on the sections for $30 \mathrm{~min}$, and sections were then incubated for 1 hour with diluted (1:50) ExtrAvidin-Horseradish Peroxidase reagent (No. E2886). After the diaminobenzidine 
reaction, a Mayer hematoxylin nuclear counterstain was applied. Negative controls consisted in the substitution of primary antisera for non-immune mouse serum. Adjacent brain-tissue sections served as positive controls.

\section{Morphometrical analysis}

Numerical cell density was determined by calculating the number of PTAH, GFAP and VIM positive cells. Five sections, roughly $50 \mu \mathrm{m}$ apart, were taken for each gland. Ten fields measuring 10,000 $u^{2}$ were randomly selected per section. Fields and sections were identical for the three staining techniques. Calculations were made manually, using projected images. Morphometrical analysis was based on random sampling, the sample being considered satisfactory when the standard deviation was less than $5 \%$ of the mean; the formula proposed by Aherne and Dunnill (1982) was employed: $n>(s / 0.05 x)^{2}$ where $n=$ number of samples, $s=$ standard deviation of sample. $X=$ sample mean, $0.05=$ desired error.

\section{Electron microscopy (EM)}

The other half of each pineal gland was used for ultrastructural analysis. Tissue blocks $\left(1 \mathrm{~mm}^{3}\right)$ were immersed in ice-cold $2.5 \%$ glutaraldehyde in $0.1 \mathrm{M}$ cacodylate buffer ( $\mathrm{pH} 7.2$ ), with or without the addition of $3 \%$ sucrose. After washing in buffer, tissue blocks were postfixed in $1 \%$ OsO4 in $0.1 \mathrm{M}$ cacodylate buffer ( $\mathrm{pH} 7.2$ ), dehydrated through a graded alcohol series and embedded in epoxy resin. Ultrathin sections were cut, stained with lead citrate and uranyl acetate, and examined with a Jeol Jem $100 \mathrm{~S}-\mathrm{X}$ electron microscope.

Immunohistochemical electron microscopy (IEM)

Ultrathin sections cut from blocks obtained for electron microscopy were stained with colloidal gold for detection of GFAP and VIM positive cells. Sections were treated with a saturated aqueous solution of sodium metaperiodate and then incubated in a moist chamber at $37^{\circ} \mathrm{C}$ with TRIS-buffered saline (TBS) $0.05 \mathrm{M}$ (pH 7.6) $+1 \%$ bovine serum albumin. Sections were subsequently incubated with primary antisera: 1:1000 monoclonal anti-human GFAP and 1:200 monoclonal anti-human VIM at $37^{\circ} \mathrm{C}$ for 3 hours. After incubation, sample sections were washed three times in TBS $0.05 \mathrm{M}, \mathrm{pH}$ 7.6. Finally, they were incubated with diluted (1:50) goat anti-mouse IgG, $10 \mathrm{~nm}$ gold conjugate (Sigma Aldrich Química, Madrid Spain; No. G-7652) for 60 minutes in a moist chamber at room temperature and contrasted with lead citrate and uranyl acetate.

\section{RESULTS}

Light microscopy: prenatal development

No PTAH positive cells were detected in groups 1 and 2. PTAH+ cells encountered in groups 3 and 4 displayed characteristics different from those observed in pinealocytes in previous groups: nuclei were small, uniform and oval or rounded in shape (Fig. 1). In both groups, these cells were uniformly distributed in perivascular clusters throughout the pineal parenchyma.

\section{Light microscopy: postnatal development}

PTAH + cells were morphologically similar in the three postnatal age-groups, differences being purely quantitative (more numerous in group II). Notably large oval nuclei were distributed uniformly over the gland surface (Fig. 2).

\section{Light immunohistochemical analysis}

GFAP+ cells were observed in the embryonic pineal parenchyma in groups 3 and 4 . In group 3 , they were distributed uniformly throughout the gland, mainly in perivascular locations (Fig. 3). These cells (which resembled in appearance the CNS astrocytes used as positive controls) displayed small, dense, ovoid nuclei, and an intensely-staining rim of cytoplasm bordering negative nuclei (Fig. 4), together with a small number of processes of varying diameters, arranged longitudinally and transversally amongst pinealocytes (Fig. 4).

In group 4 embryos, GFAP + cells were either oval or elongated in shape. Cytoplasmic processes, which were more numerous than in group 3, varied in both diameter and orientation.

In group I (the earliest postnatal age-group), the GFAP positive reaction was greater than that detected prior to birth. GFAP cells presented large somata and long processes (Fig. 5). They occurred throughout the pineal parenchyma, mainly in perivascular locations. GFAP reactivity increased in group II, where clusters of GFAP+ cells were frequently observed in the vicinity of blood vessels. In group III, GFAP+ somata and cells 


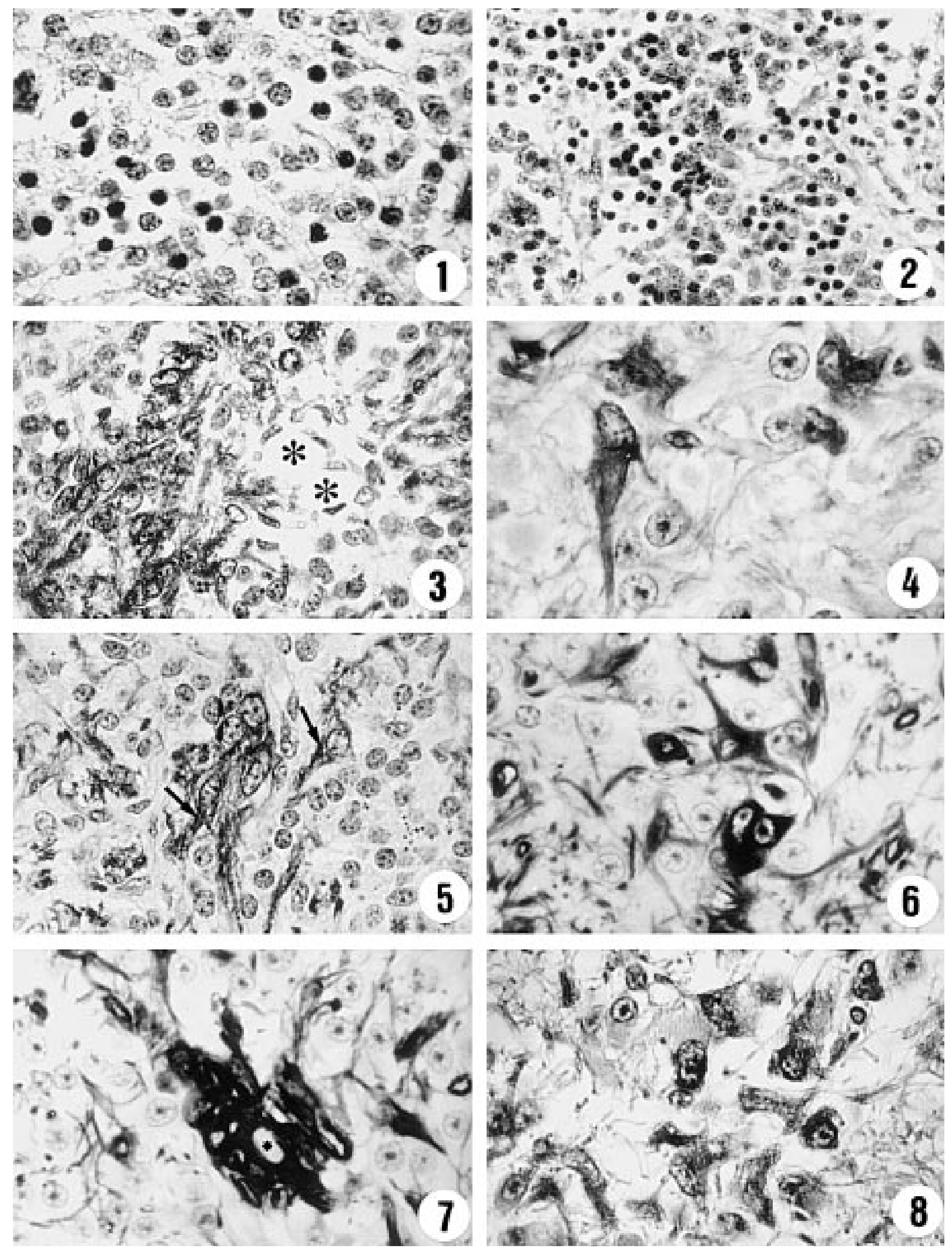


Table I

Numerical cell density of PTAH+, GFAP+ and VIM+ cells (Mean \pm standard deviation) in $10.000 \mu \mathrm{m}^{2}$ area

\begin{tabular}{lccccccc}
\hline & \multicolumn{2}{c}{ PRENATAL DEVELOPMENT } & \multicolumn{3}{c}{ POSTNATAL DEVELOPMENT } \\
\hline & GROUP 1 & GROUP 2 & GROUP 3 & GROUP 4 & GROUP I & GROUP II & GROUP III \\
\hline $\begin{array}{c}54-67 \\
\text { days }\end{array}$ & $\begin{array}{c}71-92 \\
\text { days }\end{array}$ & $\begin{array}{c}98-113 \\
\text { days }\end{array}$ & $\begin{array}{c}118-150 \\
\text { days }\end{array}$ & $\begin{array}{c}1-3-6 \\
\text { months }\end{array}$ & $\begin{array}{c}9-12-24 \\
\text { month }\end{array}$ & $\begin{array}{c}> \\
\text { months }\end{array}$ \\
\hline PTAH + Cells & & & $18 \pm 3$ & $28 \pm 4$ & $32 \pm 5$ & $45 \pm 5$ & $25 \pm 4$ \\
GFAP + Cells & & & $9 \pm 2$ & $14 \pm 3$ & $28 \pm 4$ & $41 \pm 5$ & $23 \pm 4$ \\
VIM + Cells & & & $15 \pm 3$ & $22 \pm 4$ & $20 \pm 3$ & $16 \pm 3$ & $12 \pm 3$ \\
\hline
\end{tabular}

processes were clearly less numerous than in group II. No significant differences in distribution or location were noted with respect to previous groups.

No striking differences were recorded between any groups (prenatal or postnatal) with regard to distribution of VIM+ cells within the pineal parenchyma. These cells showed less vascular tropism than GFAP+ cells.

Staining to VIM was intense in prenatal group 4. Positive cells were located close to pineal connective tissue stroma (Fig. 6) and blood vessels (Fig. 7).

During postnatal delevopment, there was a gradual decrease in the number of both positive-staining cells and cytoplasmic processes; group III cells displayed only 1 or 2 processes (Fig. 8).

\section{Morphometrical examination}

Numerical cell density of PTAH+, GFAP+, and VIM+ cells is recorded in Table I.

\section{Electron microscopy : prenatal development}

Ultrastructural analysis confirmed light microscopic findings: a second cell type (interstitial cells) was evident in groups 3 and 4, in addition to the pinealoblasts present in all groups. The interstitial cells were less numerous, more electron-dense and showed a clear preference for perivascular locations. Nuclei were rounded, with prominent nucleoli embedded in clear cytoplasm. The endoplasmic reticulum was mostly rough; the cisternae lumina were fairly narrow. Diplosomes and ribosomes were observed in perinuclear cytoplasm. The most characteristic finding in these cells was the presence of very long processes with numerous intermediate filaments.

Ultrastructurally, interstitial cells in group 4 closely resembled those observed in group 3 . These cell processes were closely associated with pinealoblast processes (Fig. 9).

\section{Electron microscopy: postnatal development}

Quantitative differences between members of the same age-group were negligible, and no significant sex-related differences were found. The following descriptions therefore apply to groups as a whole.

The intestitial cells of group I displayed two distinctive features: 1 , they were less numerous than pinealocytes; and 2, they displayed a clearly perivascular arrangement. The rounded nucleus contained nucleolus composed of a highly electrondense nucleolonema surrounding a fibrillary core. The cytoplasm was less electron-dense and contained fewer organelles than that of pinealocytes. The endoplasmic reticulum was mostly rough, and the cisternae lumina were fairly narrow. Lysosomes with clearly-defined limiting membrane were

Figs. 1/8 - (1) Embryo, 98 days. Interstitial cell nuclei are small, dense and ovoid. PTAH x 350. (2) Male sheep pineal gland. 2 years old. Interstitial cell nuclei. PTAH x 250.(3) Embryo, 98 days. GFAP+ cells close to blood vessels (asterisks) and scattered throughout the pineal parenchyma. EAS x 350. (4) Embryo, 113 days. GFAP+ cells displaying an intensely-staining rim of cytoplasm bordering negative nuclei. EAS x 500. (5) Female sheep pineal gland. 3 months old. GFAP+ cells with long cytoplasmic processes (arrows). EAS x 350. (6) Embryo, 118 days. VIM+ cells located close to pineal connective tissue stroma. EAS x 350. (7) Embryo, 150 days. Perivascular disposition of interstitial cell processes, intensely immunostained, of adjacent and contiguoes VIM + cells: EAS x 350. (8) Female sheep pineal gland. 4 years old. Moderately numerous VIM+ cells. EAS x 350. 

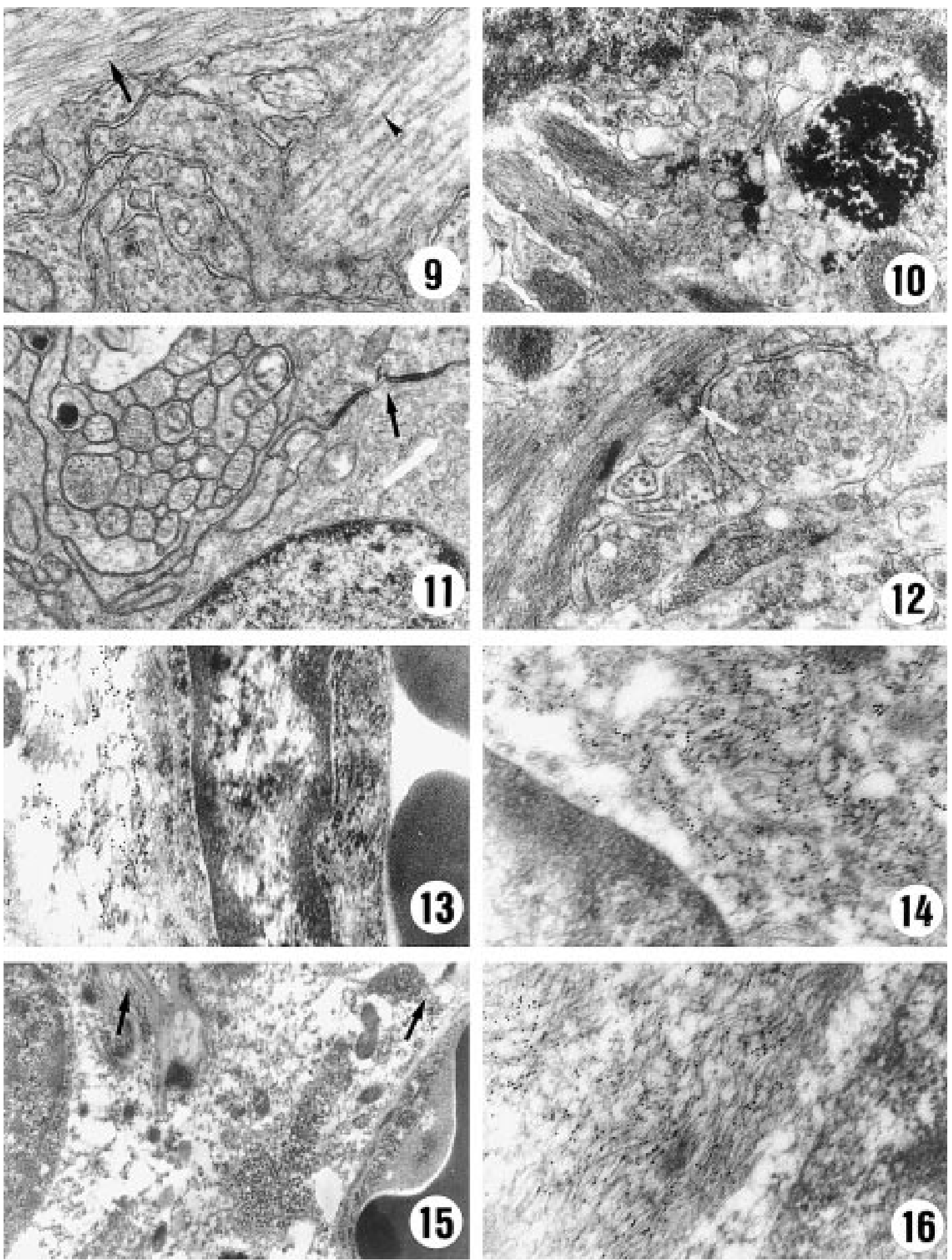
observed in perinuclear cytoplasm, together with diplosomes and ribosomes. Pigment granules, varying in both shape and electron-density, were occasionally observed. The most characteristic feature of these cells was the presence of very long processes with moderately abundant intermediate filaments.

Both pigmented (Fig. 10) and non-pigmented interstitial cells were observed in group II. Histological features were similar to those described earlier, except for:

- Greater electron-density of nucleoplasm and cytoplasm, and greater abundance of cytoplasmic organelles, particularly Golgi complexes, mitochondria and rough endoplasmic reticulum.

- Cytoplasmic processes displayed a larger number of intermediate filaments (Fig. 10), and a moderate number of gap junctions in terminal clubs (Fig. 11).

- Specific contact sites between these nerve fibers and interstitial cell processes were also detected (Fig. 12).

Ultrastructural characteristics of interstitial cells in group III were similar to those of the previous group, except for: 1) fewer intermediate filaments in cytoplasmic processes; and 2) fewer gap junctions in terminal clubs.

\section{Immunohistochemical electron microscopy}

From day 98 of gestation (group 3) (Fig. 13) through to 2 years of postnatal development (group II) (Fig. 14), GFAP expressivity, as evidenced by colloidal gold labelling, showed a progressive increase. Staining intensity decreased considerably in group III cells. In both prenatal (Fig. 13) and postnatal groups (Fig. 14), colloidal gold labelling revealed expression of GFAP by cells whose morphology closely resembled that described ultrastructurally for interstitial cells. These cells were observed in perivascular loca- tions (Fig. 13), exhibited ovoid and/or elongated non-staining nuclei, and strong cytoplasmic positivity, with clear affinity for the intermediate filaments of cytoplasmic processes (Fig. 14). Adjacent pinealoblasts remained immunonegative.

During both gestation (Fig. 15) and postnatal growth (Fig. 16), immunogold particles were detected in cells ultrastructurally resembling interstitial cells. VIM + cell morphology (Fig. 15,16) also resembled that of GFAP+ cells.

A large number of cells expressing VIM on colloidal gold labelling were detected in prenatal groups 3 (Fig. 15) and 4. Postnatal groups displayed a progressive and significant drop in immunogold particles, especially in group III (Fig. 16).

\section{DISCUSSION}

The results obtained indicate the existence of a second cell type (interstitial cells), in addition to pinealoblasts, during prenatal and postnatal development of the sheep pineal gland. Light microscopy highlighted the resemblance between these cells and the second cell type described in the pineal gland of other species, including mice and rats (Calvo and Boya 1983; Luo et al. 1984; Schachner et al. 1984; Calvo et al. 1988b; Borregón et al. 1993), golden hamsters (Huang et al. 1984), rabbits (García-Mauriño and Boya 1992), carnivores (Calvo et al. 1990; Boya and Calvo 1993; Boya et al. 1995), horses (Cozzi 1986) and ruminants (Anderson 1965; Redondo et al. 1996; Franco et al. 1997; Regodón et al. 1998 a,b). Cells displayed characteristics similar to those reported for astrocytes (Cozzi, 1986; Calvo et al., 1988b; López-Muñoz et al., 1992a,b; Boya and Calvo, 1993).

Histochemical and immunological tests were thus performed with a view to enhancing our poor knowledge of this second cell type. The first step

Fig. 9/16 - (9) Embryo, 118 days. Interstitial cell processes with numerous intermediate filaments (arrow) adjacent to pinealocyte processes with numerous microtubules (arrow head) x 20,000. (10) Male sheep pineal gland. 1 year old. Pigmented interstitial cells with numerous intermediate filaments. X 20,000. (11) Female sheep pineal gland. 2 years old. Cytoplasmic processes with more numerous intermediate filaments and presence of gap junctions (arrow) in bulbous endings x 20,000. (12) Male sheep pineal gland. 1 year old. Specific contact sites (arrow) between nerve fibers and interstitial processes $x$ 20,000. (13) Embryo, 98 days. Immune electronmicroscopic demonstration of GFAP in the cytoplasm of an interstitial cell close to a blood vessel. IEM x 30,000. (14) Male sheep pineal gland.1 year old. Immunogold GFAP+ cell, nonstained nuclei and positive cytoplasm. IEM x 30,000. (15) Embryo, 98 days. Expression of VIM in intermediate filaments (arrows) of interstitial cell processes adjacent to a blood vessel. IEM x 13,000. (16) Male sheep pineal gland. 4 years old. Positive VIM staining in intermediate filaments of interstitial cell. IEM x 30,000. 
was to determine the presence of glial-like cells by PTAH immunostaining; this was followed by immune labelling of GFAP+ and VIM+ cells. GFAP is widely considered a valid label for the detection of astrocyte development (Valentino et al., 1983), and more particularly as evidence of the presence of astrocytic cells at a certain stage of maturity (Huang et al., 1984; López-Muñoz et al., 1992a,b; Franco et al. 1997). VIM is also reported to be an excellent label for interstitial pineal cells in several species, especially rodents (Calvo et al. 1988 a; López-Muñoz et al. 1992 b; Boya and Calvo 1993; Borregón et al. 1993).

Morphometric examination revealed increased numerical density of PTAH + cells from day 98 of gestation (prenatal group 3) through to 2 years of postnatal development (group II). There was a parallel increase in the numerical density of GFAP+ cells; these, however, were always less numerous than PTAH+ cells, indicating that some glial cells (PTAH+) were not GFAP positive; this suggests the possibility of immature astrocytes (Franco $e t$ al. 1997). During gestation, there was a gradual increase in the number of VIM+ cells, although thereafter numbers fell progressively throughout postnatal development. This would confirm the validity of VIM as a marker for interstitial cells at a certain stage of maturity (Borregón et al. 1993).

Two major conclusions can be drawn from the interpretation of morphometric and immunocytochemical results: 1 , no clear relationship was noted between the number of PTAH + cells (glial cells) and the number of GFAP- and VIM- positive cells. This might be accounted for by the antigenic coexpression of GFAP and VIM in the same interstitial cell, a finding previously reported by LópezMuñoz et al. (1992 a); and 2, the interstitial cell population in developing ovine pineal gland is in fact a combination of glial-astrocyte cells at varying stages of maturity (López-Muñoz et al., 1992a; Franco et al. 1997).

Since the second cell type was detected here at 98 days of gestation, sheep can be classified as a species showing early interstitial-cell maturation. Comparison of the present results with those reported elsewhere reveals considerable discrepancies with regard to the timing of the appearance of interstitial cells. Our findings agree with those of Sozos Papasozomenos (1983), who reported their appearance in human fetal pineal gland at 24 weeks of gestation (final term). Other authors, however, disagree; Boya and Calvo (1993) made no reference to a second cell type in carnivores until the second week postpartum.

The location of interstitial cells in various mammalian species suggests that cell topography is closely linked to the anatomical location of the gland. In sheep, where the gland is deeply located within nerve structures, these cells are detected across the whole gland surface. Similar results have been reported in hamsters (Sheridan and Reiter 1970), and in cats and dogs (Boya and Calvo 1993). In rats, however, where the pineal gland is more superficially located, these cells are found only in the stalk and the most superficial portion of the gland (Luo et al. 1984; López-Muñoz et al. 1992a,b).

Ovine pineal interstitial cells appear to show morphological signs of activity from day 98 of gestation onwards. These signs appear to continue into postnatal development, attaining their maximum expression in animals slaughtered between 9 months and 2 years of age (group II). Arguments supporting this hypothetical activity include the following:

- the relationship between VIM+ and, more particularly, GFAP+ and blood vessels, already highlighted by other authors (Moller et al. 1978; Huang et al. 1984; Calvo and Boya, 1983, 1985; Sozos Papasozomenos 1983; Schachner et al., 1984; Calvo et al., 1988b; Boya and Calvo, 1993; Cozzi 1986; Borregón et al. 1993; Franco et al. 1997).

- the relationship between interstitial cells and nerve fibers. Sites of specific contact between the two were observed here, and were more abundant in the most morphologically active glands (group II). The precise functional significance of this relationship is not known, although it has been suggested that nerve fibers might be involved in interstitial cell development; indeed, these cells do not develop in the absence of innervation (Calvo and Boya 1983). Gap junctions between interstitial-cell terminal clubs were most common in animals slaughtered between the ages of 9 months and 2 years. This would appear to suggest that gap junctions play an important role in ovine interstitial pineal cells, acting as control barriers for the circulation of intercellular fluids (Cieciura and Krakowski 1991).

Morphological findings do not give grounds for confirming the functional activity of interstitial 
cells; however, there are indications of a possible exchange of substances between the pineal parenchyma and the bloodstream (Sozos Papasozomenos 1983; Schachner et al. 1984; Xu Zang et al., 1985; Suárez et al. 1987; Franco et al. 1997), which would complete the support function (similar to that of astrocytes in the CNS) traditionally attributed to these cells (López-Muñoz et al., 1992a,b).

\section{ACKNOWLEDGEMENTS}

The authors are grateful to María del Carmen González Bravo and José Luis Sanz Rodrigo of the Pathological Anatomy Unit at San Pedro de Alcantara Hospital, Cáceres and Germán Fernández Corrales of the Faculty of Veterinary Medicine, Cáceres for technical assistance.

This work was supported by the European Social Fund and the Department of Education and Youth Affairs of the Extremadura Regional Government (PRI 98 B002).

\section{REFERENCES}

Aherne W.A., and Dunnill M.S.: Morphometry. London, Arnold, 1982.

Anderson E.: The anatomy of bovine and ovine pineals. Light and electron microscopic studies. J. Ultrastruct. Res. Suppl. (8) 12, 1-80, 1965

Borregón A., Boya J., Calvo J.L., and López-Muñoz F.: Immunohistochemical study of pineal glial cells in the postnatal development of the rat pineal gland. J. Pineal Res. 14(2), 78-83, 1993.

Boya J., and Calvo J.L.: Structure and ultrastructure of the aging rat pineal gland. J. Pineal Res. 1, 83-89, 1984.

Boya J., and Calvo J.L.: Immunohistochemical study of pineal astrocytes in the postnatal development of the cat and dog pineal gland. J. Pineal Res. 15, 13-20, 1993.

Boya J., Calvo J.L., and Rancaño D.: Structure of pineal gland in the adult cat. J. Pineal Res. 18, 112-118, 1995.

Calvo J.L., and Boya J.: Postnatal development of cell types in the rat pineal gland. J. Anat. 186, 185-195, 1983.

Calvo J.L., and Boya J.: Postnatal evolution of the rat pineal gland: Light microscopy. J. Anat. 138, 45-53, 1984a.

Calvo J.L., and Boya J.: Ultrastructure of the pineal gland in the adult rat. J. Anat. 138, 405-409, 1984b.

Calvo J.L., and Boya J.: Ultrastructure of the rat pineal stalk. Acta Anat. 123, 172-177, 1985.
Calvo J.L, Boya J. and García-Mauriño J.E.: a Ultrastructure of the pineal gland in the adult dog. J. Pineal Res. 5, 479-487, 1988a.

Calvo J.L., Boya J., Borregón A. and García-Mauriño J.E.: Presence of glial cells in the rat pineal gland: a light and electron microscopic immunohistochemical study. Anat. Rec. 220, 424-428, 1988 b.

Calvo J.L., Boya J., García-Mauriño J.E. and López Carbonel A.: Postnatal development of the dog pineal gland: electron microscopy. J. Pineal Res. 8, 245-254, 1990.

Cieciura L.G. and Krakowski G.: Junctional systems in the pineal gland of the wistar rat .Ratus ratus. A freeze-fracture and thin section study. J. Submicros. Cytol. Pathol. 23 (2), 327-330, 1991.

Cozzi B.: Cell types in the pineal gland of the horse: an ultrastructural and immunocytochemical study. Anat. Rec. 216 , 165-174, 1986.

Del Rio-Hortega P.: Constitución histológica de la glándula pineal. Arch. Neurob. 3, 359-389, 1922.

Franco A., Regodón S., Masot A.J., and Redondo E.: A combined immunohistochemical and electronmicroscopic study of the second cell type in the developing sheep pineal gland. J. Pineal Res. 22, 130-136, 1997.

García-Mauriño J.E., and Boya J.: Postnatal maturation of the parenchymal cell types in the rabbit pineal gland. Histol. Histopathol. 7, 75-81, 1992.

Huang S.K., Nobiling M., Schachner M., and Taugner R.: Interstitial and parenchymal cells in the pineal gland of the golden hamster. A combined thin-section, freeze-fracture and immunofluorescence study. Cell Tissue Res. 235, 327-337, 1984.

Karasek M., and Reiter J.: Morphological aspects of the mammalian pineal gland. Microscopy Res. Tech. 21, 136-157, 1992.

Li K., and Welsh M.G.: S-antigen and glial fibrillary acidic protein immunoreactivity in the in situ pineal gland of hamster and gerbil and in pineal grafts: Develomental expresion of pinealocyte and glial markers. Am. J. Anat. 192, 510-522, 1991.

López-Muñoz F., Boya J., Calvo J.L., and Marin F.: Immunohistochemical localization of glial fibrillary acidic protein .GFAP. in rat pineal stalk astrocytes. Histol. Hispathol. 7, 643-646, 1992a.

López-Muñoz F., Calvo J.L., Boya J., and López-Carbonel A.: Coexpression of vimentin and glial fibrillary acidic protein .GFAP. in glial cells of the adult rat pineal gland. J. Pineal Res. 12, 145-148, 1992b.

Luo Z.R., Schultz R.L., Whitter E.F., and Vollrathl L.: Ultrastructural characterization of glial cells in the rat pineal gland with special reference to the pineal stalk. Anat. Rec. 210, 663-674, 1984

Moller M., Ingild A., and Bock E.: Immunohistochemical demonstration of S-100 protein and GFA protein in interstitial cells of the rat pineal gland. Brain Res. 140, 1-13, 1978. 
Redondo E., Franco A., and Regodón S.: Prenatal development of the sheep pineal gland: An ultrastructural study. J. Pineal Res. 21 (3), 140-148, 1996.

Regodón S., Franco A., Masot A.J., and Redondo E.: Structure of the ovine pineal gland during prenatal development. J. Pineal Res. 25, 229-239, 1998a.

Regodón S., Franco A., Gázquez A., and Redondo E.: Presence of pigment in the ovine pineal gland during embryonic development. Histol. Histopathol. 13, 147-154, 1998 b.

Schachner M., Huang S.K., Ziegelmuller P., Bizzini B., and Taugner R.: Glial cells in the pineal gland of mice and rats. A combined immunofluorescence and electron-microscopic study. Cell Tissue Res. 237, 245-252, 1984.

Shedpure M., and Kumar A.: The pineal gland: structural and functional diversity. Indian J. Exp. Biol. 33, 625-640, 1995.
Sheridan M.N., and Reiter J.: Observations on the pineal system in the hamster. II: Fine structure of the deep pineal. J. Morphol. 131, 163-177, 1970.

Sozos Pasozomenos C.H.: Glial fibrillary acidic GFA Protein-containing cells in the human pineal gland. J. Neuropathol. Exp. Neurol. 42, 391-408, 1983.

Suárez I., Fernández B., Bodega G., Tranque P., Olmos G., and García-Segura L.M.: Postnatal development of glial fibrillary acidic protein immunoreactivity in the hamster arcuate nucleus. Devel. Brain Res. 37, 89-95, 1987.

Valentino K.L., Jones E.G., and Kane S.A.: Expresion of GFAP immunoreactivity during development of long fiber tracts in the rat CNS. Devel. Brain Res. 9, 317-336, 1983.

Xu Zang X., Nilaver G., Stein B.M., Fettel M.R., and Duffy P.E.: Immunocytochemistry of pineal astrocytes: species differences and functional implications. J. Neuropathol. Exp. Neurol. 44, 486-495, 1985. 